\title{
Enforcing Margin Squeeze Ex Post Across Converging Telecommunications Markets.
}

Bergqvist, Christian; Townsend, John

Publication date:

2015

Document version

Early version, also known as pre-print

Citation for published version (APA):

Bergqvist, C., \& Townsend, J. (2015). Enforcing Margin Squeeze Ex Post Across Converging

Telecommunications Markets. (pp. 1-31). Konkurrensverket. Konkurrensverket - Working Paper Vol. Working Paper 2015:2 


\section{WORKING PAPER SERIES \\ IN LAW AND ECONOMICS}

\section{Enforcing Margin \\ Squeeze Ex Post Across Converging Telecommunications Markets}

Christian Bergqvist and John Townsend 
Konkurrensverket Working Paper series in Law and Economics covers current research topics in the field of competition and public procurement policy that may be of interest to a wider public.

Opinions expressed are those of the author(s) and do not necessarily represent the views of Konkurrensverket. 
Konkurrensverket Working Paper Series in Law and Economics

Enforcing Margin Squeeze Ex Post Across Converging Telecommunications Markets

\author{
Christian Bergqvist and John Townsend ${ }^{1}$
}

\begin{abstract}
A margin squeeze is an exclusionary abuse which occurs when a vertically integrated telecoms operator creates a disparity between upstream and downstream prices with the intention of squeezing an access competitor's profits. The purpose of such pricing is either to increase the latter's entry costs, delay profitability or limit their ability to remain or expand on markets. However, traditional market definitions are being challenged by (1) the technological convergence of services and (2) innovative product offerings taking advantage of this convergence. Consumers now routinely purchase a bundle of telecoms services with a single payment (known as 'quad play'), including fixed and mobile voice calls, broadband connectivity, and premium broadcasting content. How should such unilateral conduct be assessed ex post by a competition authority under Article 102 TFEU? We suggest that convergence and innovation present both theoretical and practical difficulties for assessing "muddled margins" on telecoms markets. New and different enforcement approaches to exclusion will have to be formulated within the Article 102 framework and tested in the Courts. This may even require abstaining from applying Article 102 TFEU during material periods of convergence, and confining ex post enforcement activity to sector regulation, even when this is inferior for safeguarding effective competition.
\end{abstract}

\footnotetext{
1 Christian Bergqvist is an associate Professor at the University of Copenhagen. John Townsend is a barrister at Devereux Chambers, London. The views expressed in this article are personal. Comments are welcome at cbe@jur.ku.dk and townsend@devchambers.co.uk. The authors are grateful to Vian Quitaz for inviting them to give a presentation on which this Working Paper is based to the Konkurrensverket in Stockholm on 12 May 2015.
} 


\section{Table of Contents}

\section{Introduction}

II. Theoretical debates and uncertainties

III. Margin squeeze in early and mature EU decisional practice
(a) Early practice
(b) Mature practice: from Deutsche Telekom to Telefónica
(c) Other cases contributing to margin squeeze

IV. An emerging, but not necessarily prudent, enforcement consensus?

V. Technological convergence and market definition: muddled margins or muddled methodologies?
(a) A renewed focus on consumers
(b) Risks of methodological errors
(c) Final conclusions 


\section{Introduction}

In competition policy, it is well established that an abuse of a dominant position by an unlawful margin squeeze is an infringement of Article 102 TFEU. While early practice left a number of open questions, most were settled gradually as the case law matured before European Courts, concluding with Deutsche Telekom ${ }^{2}$ in $2010 .^{3}$ Many of these cases arose from enforcement action by the EU Member State competition authorities, or the European Commission or National Regulatory Authorities (NRAs) for telecoms. Similarly, in U.S. antitrust law (where the abuse is usually known as a 'price squeeze') there is a rich Supreme Court jurisprudence applying the concept to telecoms markets. ${ }^{4}$ Put at its broadest, the present consensus on margin squeeze seems to be that, in fixed line markets, there must be an inadequate upstream and downstream margin on the facts and exclusionary effects established by a credible theory of harm. Some commentators, such as Dunne (2012) have suggested that there is a "widening gap" between U.S. and EU approaches to margin squeeze. ${ }^{5}$ To be sure, Geradin and Sidak (2005) identified potential U.S. - EU divergence due to the "luxury" of the EU's systematic approach driven by the common market imperative (as opposed to the more incremental texture of U.S. antitrust law). ${ }^{6}$

In this paper, however, we suggest that different regulatory gaps are opening: not between jurisdictional variations of approaches to defining markets or particular costs standards, but between the concept of margin squeeze itself and the way telecommunications services are consumed. Legally and economically, this primarily impacts market definition. Soon, EU consumers will routinely purchase premium broadcast content (such as sporting events) streamed direct to their TVs and mobile phones, paid for as part of a single bundle, including fixed-line telephony and broadband to their principal residence (“quad play"). Assigning and evaluating the costs of these network services for margin squeeze purposes is a complex exercise.

2 Case C-280/08P - Deutsche Telekom, [2010] ECR I-9555. See recital 183 (separate abuse) and recitals 196-204 (definition and applicable cost standard).

A degree of uncertainty can be detected in the Commission decision. C.f. case COMP/37.451 Deutsche Telekom AG, O.J. 2003L 263/9, recital 199 where the abuse are defined as consisting of "...charging unfair prices...caught by Article 82(a) of the EC Treaty" labelling margin squeeze as a form of excessive pricing.

See the useful Amicus Curiae brief authored by Robert Bork and Gregory Sidak in Pacific Bell $v$. LinkLine 555 U.S. 438 (2009) for a list of relevant cases, but see in particular AT\&T v. Iowa Utilities Board, 525 U.S. 366 (1999); Cavad Communications v. Bell Atlantic Corp., 398 F.3d 666 (D.C. Cir 2005).

$5 \quad$ Niamh Dunne, "Margin Squeeze: Theory, Policy, Practice", ECLR 2012 33, pp. 29 and 61.

6 Damien Geradin and J. Gregory Sidak, "European and American Approaches to Antitrust Remedies and the Institutional Design of Regulation in Telecommunications", American Enterprise Institute, p. 14. 
We consider that such technological convergence allows dominant telecoms companies to "muddle" margins across different markets through unilateral conduct. We suggest therefore that the muddling of margins in telecommunications markets is driven by the two complementary developments of (a) technological convergence; and (b) pricing innovation. It is important to note that only (b) is unilateral conduct that can be evaluated under traditional approaches under Article 102 TFEU. The incomplete nature of margin squeeze enforcement is not in our view best explained by some aspect of regulatory capture but due to difficulties with the trends of innovation and convergence for the legal concept. ${ }^{7}$ Competition authorities looking to past decisional practice and case law to evaluate margins on converging telecoms markets will struggle to assess fairly the nature of competition on these dynamic markets. We seek to illustrate this thesis with a particular focus on the technological development of services on telecoms markets and the legal tools available to assess, deter and punish anticompetitive conduct on those markets. A complimentary trend of market consolidation in mobile markets (often owned or operated in an integrated fashion by fixed line operators) is reducing the number of mobile network operators active on most EU markets, and may prompt in-depth merger control scrutiny of such transactions. ${ }^{8}$ To be sure, most network industries, and particularly those with cost models that incorporate multiproduct offerings in a single price (of which telecoms is germane) have always had the practical issue of attributing common costs to individual services. ${ }^{9}$ However, technological convergence and its implications for unilateral conduct have not been satisfactorily explored. The economic issue is not just how competitors access an incumbent's network, but the terms on which access is offered in a converged market. This rider is well-established from the case-law, although we consider that there is scope for considerable uncertainty for a competition authority to draw effects-based conclusions.

\footnotetext{
$7 \quad$ With respect to Ofcom's TalkTalk (CW/01103/03/13) non-infringement decision of 2014 as to bundled premium sports content and broadband under Article 102 TFEU, suggestions of capture were made on Chillin Competition blog ("Regulating TV markets to protect BT? Not again, Ofcom. Please") in March 2015. Within the EU context, however, Ofcom is relatively unusual in that it is an NRA for telecoms but also provided with concurrent competition law enforcement powers for particular communications markets, including regulated telecommunications services.

$8 \quad$ See M.7419, TeliaSonera / Telenor JV and also Tobias Caspary and Lars Görlitz, "EU Merger Control and Mobile Telecoms - consolidation at the cost of competition or regulation hampering the creation of European champions?", (2015) 36 ECLR, Issue 5, 211-299. They conclude at p. 218: "The Commission's recent investigations indicate that any consolidation down to fewer than four MNOs will likely lead to an indepth Phase II investigation, and most likely, require a complex and comprehensive remedy package." (Normally, sponsored entry of one or more virtual operators.)

See the debates as to the 'relevant output increment' in the European Commission's decision in Deutsche Telekom, recitals 125-137.
} 
Before we consider the concept of margin squeeze under Article 102 TFEU further, we note at the outset that the consensus position has some important practical qualifications:

1. The dominant position could be either upstream or downstream and the contemplated foreclosure could be directed by the dominant undertaking in both

directions. In the telecoms sector, the wholesale market for infrastructure forms the natural base for a leverage strategy. In this scenario, the downstream retail market would be the objective. The foreclosure can therefore be achieved by either raising the wholesale price or lowering the retail price. Potentially, selective (and discriminatory) discounts could be reserved for the downstream activities of the dominant undertaking. Consequently, in this scenario margin squeeze overlaps with other forms of abuse, including excessive and predatory pricing, and discrimination. ${ }^{10}$

2. While not a legal requirement, practically the dominant position of the incumbent must be unassailable for the foreclosure to be effective. A margin squeeze therefore normally requires a monopoly or a super-dominant market position. Otherwise, any leverage attempts could undercut the incumbent's long-term control of the market. ${ }^{11}$ Further, the value of the involved services or products must not be trivial or non-essential for market access but rather account for a substantial part of the value of the downstream products or services. Otherwise a vertical foreclosure will not be feasible. ${ }^{12}$ Consequently, a margin squeeze is a variation of a refusal to supply and should in principle be subject to the same legal requirements.

3. The relationship (margin) between the wholesale and retail price must be unfair in light of the assessment of the costs of those services. Any assessment involves choices within a process by a competition authority. There are various cost standards which have been applied, and competition authorities retain considerable discretion as to their application. Prices can be assessed against the dominant undertaking's own costs and ability to remain viable had it been compelled to pay the levied wholesale prices, referred to as the equally efficient competitor standard. An alternative is the reasonably efficient

10 See e.g. case COMP AT.39.678/AT.39.731 - Deutsche Bahn I/II and COMP/39.402 - RWE gas foreclosure, where applying discriminatory terms was viewed as a form of margin squeeze. Both cases where closed against remedies and never finalized. In the UK, Ofcom's BT Together investigation of 2008 considered the incumbent's market for termination and hosting calls as unlawful discrimination under Article 102 2(c). No discrimination was found following an assessment of the margin.

11 C.f. Massimo Motta, Competition Policy, Theory and Practice, (Cambridge, 2004), pp. 341 and 373 , note 70: theoretically, if an input price is prohibitively high, demand decreases to zero.

12 See e.g. the Guidelines on the assessment of non-horizontal mergers under the Council Regulation on the control of concentrations between undertakings, recital 34-39 in respect to vertical mergers. The offered observations should be translatable to a vertical foreclosure. 
competitor standard, under which it is accepted that certain competitor-specific cost components are included provided they over the long run could be equally efficient as the dominant competitor. ${ }^{13}$ This alternative might be relevant where the dominant undertaking is only more efficient because of economic of scale or scope or prior control of (infrastructure) assets. The as-efficient or equally efficient test is a conservative, proincumbent test.

\section{It might be relevant to make a distinction between foreclosing of existing competitor} and more strategic pre-emptive closing of markets prior to their entry. As market access normally requires a number of initial investments, which dominant undertakings already have made, pre-emptive foreclosure would presumably be easier to implement by compelling the enforcer to consider a different (and stricter) cost standard test. ${ }^{14}$ Further, actual foreclosure is not required for the squeeze to be successful. A disciplinary or deterrent effect compelling newcomers to take the competitive pressure vicariously would be sufficient to diminish competition and hurt consumer welfare.

\section{The squeeze can comprise a portfolio of products or a single product, ${ }^{15}$ and can} therefore be selective and strategic in the same manner as predatory pricing. The vertically integrated dominant undertaking will often offer a bundle of comparable products with a range of prices, leading to an enforcement need to choose the aggregation level for the assessment of margin squeeze.

Despite these five qualifications, margin squeeze is a genuine phenomenon in the telecoms sector. Cases and enforcement action have occurred in all major EU states. This fact only heightens the importance of justifiable methodologies, clear enforcement priorities and efficient remedial implementation for competition authorities.

This risk of mislabeling other forms of unilateral conduct as margin squeeze has implications for increasing the risk of mistakes. In this paper, we adopt the classic dual typology for the categorization of such enforcement errors:

\footnotetext{
13 For further on the two standards see Geoff Edwards, Margin squeezes and the inefficient "equally efficient" operator, ECLR 2011, 32(8), pp. 402-405; and Robert O’Donoghue \& Jorge Padilla, The Law and Economics of Article 102, $2^{\text {nd }}$ edition, Hart Publishing, 2013, pp. 376-382.

14 See John Kallaugher, The "Margin Squeeze" under Article 82: Searching for Limiting Principles, paper from Conference organized by the Global Competition Law Centre (GCLC) in association with British Telecommunications plc, BT Center, London, 10 December 2004, pp. 16 and 32.

15 C.f. COMP/38.784 - Telefónica, recitals 386-388.
} 
- "Type I errors", where competition law is used to condemn genuine pro-competitive or neutral behavior not detrimental to the consumer welfare. This is a false positive decision, or in layman's terms "convicting the innocent."

- "Type II errors", where competition law fails to condemn anti-competitive behavior detrimental to the consumer welfare. This is a false negative decision, or in layman's terms "acquitting the guilty."

Hypothetically, sound competition law enforcement on telecommunications markets could be performed either under ex ante sector regulation or ex post competition law. The ex post actor for margin squeeze enforcement could be either the administrative process of an EU Member State's competition authority or the European Commission; or alternatively actions before a Court, by a public prosecution before a Court by a competition authority (as in the U.S.), or a private Court action brought by a competitor. Before contemplating how administrative ex post competition law enforcement has developed in EU competition law, we revisit some of the qualifications set out above in light of theoretical debates. Our view is that these qualifications of a margin squeeze make ex post infringement decisions under competition law a less than satisfactory exercise.

\section{Theoretical debates and uncertainties}

It is widely noted in the theoretical literature that the enforcement effects of prohibiting margin squeeze are ambivalent for consumers. Bork and Sidel (2009) argue that the "primary concern in price-squeeze cases is not consumers but competitors..." 16 If this is so, why prohibit margin squeeze? Jullien, Rey and Saavadra (2013) suggest that, “...absent exclusionary effects, banning margin squeeze benefits the independent competitor, hurts the integrated firm and may or may not benefit final consumers. In addition, a ban on margin squeeze raises incentive to foreclose the upstream market." 17 This begs the further question of how, in regulated intermediate markets, dominant telecoms companies have the ability to squeeze prices in the first place. The same authors acknowledge that, "...to the extent that access regulation is imperfect [there is a need for]...antitrust scrutiny and ex post intervention in case of abuse." 18 The existence of margin squeeze is therefore usually explained as a means of policing the residual unilateral discretion of a dominant vertically

16 Amicus Curiae brief, Robert Bork and Gregory Sidak in Pacific Bell v. LinkLine 555 U.S. 438 (2009) at $\mathrm{p}_{17} 7$.

18 Jullien, Rey and Saavadra, "The Economics of Margin Squeeze," October 2013, pp. 31-32. Jullien, Rey and Saavadra, n 17, (2013), p. 34. 
integrated operator to perform an exclusionary pricing strategy on intermediate markets. As Ofcom, the UK's competition authority for communications markets, including regulated telecoms services, emphasized in the THUS / Gamma non-infringement decision of 2013:

"Competition law seeks to protect competition on its merits for those elements of the value chain which are contestable. By protecting such competition, consumers are able to benefit through the lower prices associated with output being delivered over the most efficient infrastructure. Absent from the protection of competition law, vertically integrated operators would be at liberty to engage in the types of exclusionary strategies identified above. Where such strategies lead to the successful elimination, or weakening, of competition to the vertically integrated firm in the downstream market, consumers will fail to gain from the benefits of competition." 19

Yet while the vertically integrated operator may always have the ability to pursue a vertical leverage strategy, the incentive to do so might not always be present. ${ }^{20}$ It would even in our view be plausible to presume that intermediate customers will always anticipate a margin squeeze and consider alternative suppliers or establish themselves upstream, undermining the incumbent's dominant position over the long run. ${ }^{21}$

Further, the rational dominant undertaking might not find it profitable to exclude the downstream customer at the cost of its upstream profit. If it is assumed that downstream newcomers are more competitive than incumbents on downstream activities, the net gain by an effective foreclosure by a dominant company could well be negative. The presence of economics of scale and scope, network effects and in particular upstream price regulation and an obligation to serve capping the ability to repatriate the full profit, might, however, displace this assumption. ${ }^{22}$ While the level of economics of scale and scope, and also the operation of network effects in a telecoms market might be debatable, the persistent presence of regulation in our view makes the risk of a vertical foreclosure real. There is a particular risk of a vertical foreclosure in a telecoms market in the early phases of the liberalization process, where the incumbent will retain a position of monopoly at all levels of the supply chain, and even during later stages where the infrastructure might remain a bottleneck. Consequently, the ability to police such conduct under Article 102 TFEU should be an important enforcement priority of competition authorities. For the purpose of rationalizing anti-competitive behavior

\footnotetext{
19 Ofcom, THUS / Gamma (CW/00988/06/08) (20 June 2013) at para. 7.254.

20 This is expressly acknowledged in the responses to Ofcom's draft statement in Fixed Access Market Reviews: Approach to the VULA Margin (19 March 2015), at paras. 3.23-3.26, 3.39-3.40, 3.65-3.76.

$21 \quad$ C.f. e.g. the merger case M.2738 - GEES/Unison, recital 19.

22 C.f. OECD Reports, Restructuring Public Utilities for Competition August 2001, pp. 10-11; and Robert O'Donoghue \& Jorge Padilla, The Law and Economics of Article 102, $2^{\text {nd }}$ Edition Hart Publishing 2013, pp. 368-371. Ofcom, for example, requires this in certain markets.
} 
in the telecoms sector, the European Regulatory Group (ERG) under the EU Commission, ${ }^{23}$ published a paper in $2006^{24}$ identifying 27 examples of standard competition problems in these circumstances. Of these, no fewer than eleven support a vertical leverage strategy directed at either squeezing the margin, raising costs or restricting sales. The 11 examples have been set out in an overview by ERG. ${ }^{25}$

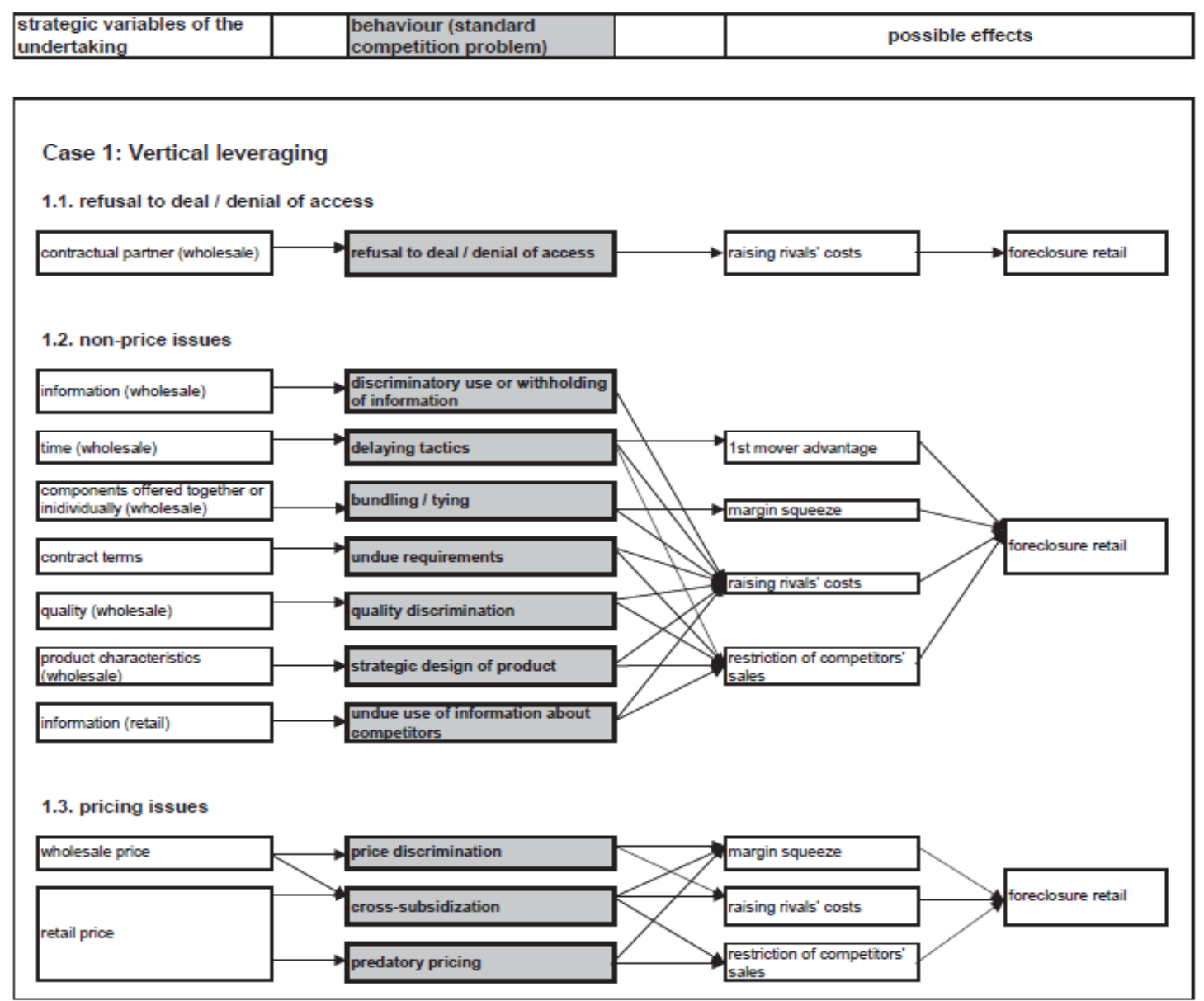

The ERG paper was developed for the purpose of considering appropriate regulation under EU telecoms sector regulation, but conceptually this table is easily translated into equivalent provisions of competition law. The first notable point is that ERG does not identify margin squeeze as anti-competitive behavior, but merely as a manifestation of other abusive conduct. Hence, it could be considered that rather than condemning margin squeeze as anti-competitive and an infringement of Article 102 it should be viewed as a variation of

23 The ERG was established by Commission Decision 2002/627/EC, as amended by 2004/641/EC for the purpose of facilitating corporation and discussions between national telecom authorities and the Commission.

Revised ERG Common Position on the approach to appropriate remedies in the ECNS regulatory framework, (ERG (06)33), 2006, pp. 39-40.

${ }_{25}$ The overview is taken from Revised ERG Common Position on the approach to Appropriate remedies in the ECNS regulatory framework, (ERG (06)33), 2006, pp. 39-40. We are grateful to reproduce it here. 
other forms of infringement and only be condemned under these standards. This is in line with the initial opening remarks of this Working Paper as to how margin squeeze could be considered as a variation of excessive and predatory pricing or discrimination and should be rendered subject to the same principles as a refusal to supply. Originally, this might also have been the position under EU Competition law, and as it shall be developed further, it was in our view not without some merit.

\section{Margin squeeze in early and mature EU decisional practice}

For the purpose of understanding what can make margin squeeze troublesome as a matter of enforcement, we will, in this section, review the early and mature EU decisional practice on margin squeeze from a critical perspective. This is done to consider what learning national enforcers may take from the centre in applying their considerable national discretion for margin squeeze enforcement. It is apparent from the jurisprudence that margins are assessed on a case-by-case basis, within a range of potentially acceptable methodologies approved by the Courts as a consensus position. We also consider other case law which does not easily fit into the consensus position. It is important to note that the policing of margin squeeze is normally performed ex post across EU Member States by national competition authorities, within the constraints for lawful competition set prospectively ex ante by NRAs for telecoms in regulatory matters. ${ }^{26}$

\section{(a) Early practice}

As with so many aspects of EU Competition law, early practice on margin squeeze is difficult to reconcile with subsequent developments. The concept was first introduced to EU competition law by the Commission through National Carbonizing Company ${ }^{27}$ in 1975 . No abuse was, however, identified in that case, leaving open a great deal of issues. These included: e.g., if dominance is required both upstream and downstream as a precondition for infringement and appropriate methodologies for cost standards: the as-efficient competitor or the reasonably efficient competitor. Both cost standards could be extracted from the considerations offered by the Commission. The principle from National Carbonizing

26 Of course, not all markets or services are regulated, but all are subject to ex post competition law enforcement. The UK's NRA Ofcom is unusual for combining both functions, having the ability to enforce competition law concurrently in conjunction with the Competition and Markets Authority. Many other Member States do not have this dual 'Janus-face' ability.

27 76/185/ECSC: Commission Decision of 29 October 1975 adopting interim measures concerning the National Coal Board, National Smokeless Fuels Limited and the National Carbonizing Company Limited O.J. 1976L 35/6. 
Company was developed further with British Sugar/Napier Brown ${ }^{28}$ from 1988 where, in contrast, an abuse was found, albeit not in respect of the creation of an unfair margin but rather a toxic cocktail of refusal to supply, price discrimination, tying, loyalty discounts and selective price cuts in the retail market. In contrast to National Carbonizing Company, the Commission noted in British Sugar/Napier Brown that the involved undertaking was dominant at both retail and wholesale level, perhaps indicating this as a precondition for the identified abuse, followed by observation that the dominant undertaking's own costs were the applicable cost standard.

Neither of the cases indicates that margin squeeze constituted a separate infringement of Article 102 TFEU, however, and we consider that these early statements of principle are difficult to align with the present consensus on margin squeeze. Equally, less can be extracted from $I P S^{29}$ of 2000 , which was the first margin squeeze case reviewed by the General Court. $^{30}$ The IPS case does, however, indicate that a surcharge could be justifiable where the purchaser has special requirements due to different production form regardless of the consequences for the profitability. To the extent that principles can be extracted from IPS it would appear to be that the applicable cost assessment does not include customer specific costs attributable to decisions on a particular business strategy.

\section{(b) Mature practice: from Deutsche Telekom to Telefónica}

The early practice did little to provide a clear standard for reviewing margin squeeze allegations and did not even identify the abuse as a separate infringement of Article 102 TFEU. These issues would be settled as the case law matured. The first mature case was Deutsche Telekom, ${ }^{31}$ closed finally by the Court of Justice in 2010, which established margin squeeze as a separate infringement. ${ }^{32}$ The Court held that an abuse was found even when the wholesale price had been prospectively regulated by the NRA for telecoms. This meant that higher retail prices mandated by the Commission for the dominant undertaking were the sole

\footnotetext{
28 Case IV/30.178 - Napier Brown - British Sugar, O.J. 1988L 284/41. See in particular recitals 25, 30 and 64-76.

${ }_{29}^{29}$ Case T-5/97 - Industrie des poudres sphériques SA, ECR. 2000, p. II-3755. See recitals 179 (no separate abuse) and 157-167 (surcharge justifiable).

30 Partly due to the nature of the case as it involved action against the Commissions alleged failure to pursue a lodged complain adequately.

Case C-280/08P - Deutsche Telekom, ECR 2010, p. I-9555. Recitals 183 (separate abuse) and 196-204 (definition and applicable cost standard).

32 A degree of uncertainty can be detected in the Commission decision. C.f. case COMP/37.451 Deutsche Telekom AG, O.J. 2003L 263/9, recital 199 where the abuse are defined as consisting of “...charging unfair prices...caught by Article 82(a) of the EC Treaty" labelling margin squeeze as a form of excessive pricing.
} 
available remedy to ensure that the dominant undertaking stopped the abuse. A remedy difficult to justify by reference to the consumer welfare standard as a matter of competition law. In contrast, the Court held that whether the risk of foreclosure caused by the pricing conduct was real or not could not be ignored for the assessment of the infringement, as suggested by the Commission. However, the creation of an entry barrier could be sufficient for foreclosure, ${ }^{33}$ allowing also for coverage of more strategic and preemptive moves. As the involved undertaking was dominant at wholesale and retail levels and had charged wholesale prices occasionally above the retail price, the abuse was less difficult to deny by the dominant firm. Consequently, it was not imperative for the Court of Justice to decide on the applicable cost standard used to evaluate the margin squeeze. The General Court did, however, for the purpose of legal certainty, express a preference for the dominant undertaking's own cost base and hence the as-efficient competitor ${ }^{34}$ standard.

Other novelties in Deutsche Telekom lay in the provided analysis for the calculation of cost and revenue. ${ }^{35}$ The wholesale price, levied for the competitor, considered costs using the regulated wholesale price including a surplus for opening or taking over a connection, divided by the expected lifetime of a subscription. With respect to revenue and product specific costs, the applied calculations were more complex, partly because of the products and services delivered through wholesale local loop access, including voice telephony and broadband. In contrast to the company, the Commission did not find it relevant to include dial-up charges in the calculations, despite the generated cash flow. This was justified by reference to sector regulation making a distinction between charges for the subscription and the actual use. Further, the Commission had adopted "...The method...based on the principle that the established operator's tariff structure must enable competitors to compete with that operator effectively, and at least to replicate the established operator's customer pattern.",36 With respect to calculating the (downstream) product specific cost for the purpose of checking if the margin secured coverage, it was decided to include general customer costs, ${ }^{37}$ and certain extra costs e.g. the need to install equipment at the customer. In contrast, network costs were not included, as this were considered part of the wholesale price.

\footnotetext{
33 Case C-280/08P - Deutsche Telekom, ECR 2010, p. I-9555, recital 250-259.

34 Case T-271/03 - Deutsche Telekom, ECR 2008, p. II-447, recital 188-192.

35 Case COMP/37.451 - Deutsche Telekom AG, O.J. 2003L 263/9, recitals 111 (weighted average), 112137 (retail revenue), 138-141, 155-159 (product cost) and 149-151 (wholesale price).

Case COMP/37.451 - Deutsche Telekom AG, O.J. 2003L 263/9, recital 127.

37 I.e. marketing, maintaining and invoicing costs c.f. recital 156.
} 
There are several elements in Deutsche Telekom that recast the principles established in the early practice. In IPS, competitor-specific costs, in contrast to Deutsche Telekom, were not included in the cost standard. ${ }^{38}$ Further, the product specific costs appears to have been calculated by a higher standard than previously, ${ }^{39}$ while the revenue was evaluated against principles derived from sector regulation adopted to secure beneficial access for new comers. In our view, both elements inescapably give competition law a flavour of sector regulation. ${ }^{40}$ Neither the General Court nor the European Court of Justice had reservations about the Commission's approaches save for the requirement of a foreclosure risk. ${ }^{41}$ Further, they appear to have endorsed the use of the dominant undertaking's own costs and the as-efficient competitor standard for the purpose of self-assessment and legal certainty. This is to be used even where the dominant firm Deutsche Telekom might have been subject to costs not levied upon competitors, and was potentially more efficient than indicated by the costs calculations.

The regulatory overview by the NRA and the approach to cost and revenues also played a pivotal role in later telecom cases. In Telefónica ${ }^{42}$ decided by the Commission in 2006 and upheld by the European Court of Justice in 2014, regulatory overview by the NRA was invoked in defence of the abuse. Unsuccessfully, perhaps in light of the regulation being limited to wholesale prices, it was decided that the higher retail price was available for the dominant undertaking had it had a genuine interest in avoiding squeezing the competitors (as claimed). ${ }^{43}$

Slightly different, but largely with the same result, was the situation in TeliaSonera ${ }^{44}$ from 2011. In this case, wholesale access had been granted without legal obligation and in a

38 C.f. Geoff Edwards Margin Squeezes and the Inefficient "Equally Efficient Operator", ECLR 2011 32(8), p. 402. Further the Commission appears to include a profit at the wholesale market as part of the costs c.f. COMP/37.451 - Deutsche Telekom AG, recitals -128 .

39 C.f. John Kallaugher, The "Margin Squeeze” under Article 82: Searching for Limiting Principles, paper from Conference organised by the Global Competition Law Centre (GCLC) in association with British Telecommunications plc, BT Centre, London, 10. December 2004, pp. 16 and 32.

$40 \quad$ A perception enhanced further by the incorrect implementation of sector regulation in Germany c.f. Robert O'Donoghue \& Jorge Padilla, The Law and Economics of Article 102, $2^{\text {nd }}$ Edition, Hart Publishing, 2013 , p. 418 , note 210 .

41 See the summary in case T-271/03 - Deutsche Telekom AG, ECR 2008, p. II-477, recitals 165-168, 192-193, 203-207 \& 211. The case related to the pre-emptive foreclosure rather than actual excluding of a competitor and should perhaps be reviewed in light of this.

42 Case COMP/38.784 - Telefónica. Confirmed by General Court in case T-336/07 - Telefónica, SA and Telefónica de España, SA, and European Court of Justice in case C-295/12P - Telefónica SA and Telefónica Espana.

43 See also recital 630 where the Commission notes how Telefónica could have avoided engaging in a margin squeeze by lowering its wholesale prices.

44 Case C-52/09 - Konkurrensverket mod TeliaSonera Sverige AB, [2011] ECR I-527, recitals 6 (voluntarily opening) 34, 55-58 (separate infringement), 31-33, 45 (legal standard), 72 (indispensability) 89 (dominance at one or two markets) and 96-103 (recoupment). 
situation where the conditions for a refusal to supply case under Article 102 TFEU most likely was not met. TeliaSonera, a national case referred to the Court of Justice for a preliminary ruling in the period between the Commission's decision and the General Court's review of Telefónica, reconfirmed margin squeeze as a separate infringement. The Court held that margin squeeze is neither governed by the principles of other infringements, including refusal to supply, nor conditioned upon the identification of such a separate abuse. ${ }^{45}$ Further, it was not considered a precondition to identify long-term recoupment, factual exclusion or a dominant position at both the wholesale and retail levels. A margin squeeze could be found when the spread between the retail and wholesale price was negative or failed to secure coverage of the dominant undertaking's own product-specific cost, potentially excluding an as-efficient competitor. ${ }^{46}$ However, in certain limited situations, the Court of Justice opened a window for using the costs and prices of a competitors as an alternative: e.g. if, for objective reasons, the costs of the dominant undertaking are unavailable; or the requested service was utilizing a infrastructure that has already been written-off and no longer representing a cost for the dominant undertaking; or if the dominant undertaking somehow had lower costs due to being in a competitively advantageous situation. While not articulated directly, these remarks in our view indicate the use of a reasonably efficient competitor standard as an alternative to evaluate costs is still available in law. The alternative is likely available if the as-efficient competitor test would render a misleading result, perhaps in the presence of substantial economies of scale and scope or substantial entry cost for newcomers in contrast to the incumbent. Further, a margin squeeze could either be demonstrated by finding a negative margin between wholesale and retail prices, or following more substantial analysis of the costs, that these where not covered at all by the margin.

As the General Court relied on TeliaSonera substantially in Telefónica, it primarily offers value as to the understanding of appropriate measures of revenue and costs. $^{47}$ In Telefónica the later were calculated using LRAIC, ${ }^{48}$ and including variable and fixed costs, a

\footnotetext{
45 Despite rebutting the requirement of applying the rigid requirement of the refusal to supply standard i.e. an essential product, the Court of Justices does, perhaps, reintroduce it in recital 77 by contemplating the abuses ability to create a foreclosure.

46 This might imply that a negative margin is not a requirement if e.g. the competitor is more efficient or willing to accept a reduced rate of return c.f. recitals 32-33. For a critical review of this see Nicolas Petit Price Squeezes with positive margins in EU competition law: Economic and legal anatomy of a zombie, SSRN, (2014).

47 Despite disregarding the need to identify an essential infrastructure c.f. the refusal to supply doctrine, it's nevertheless accepted that the requested infrastructure most likely would meet this requirement in the absence of alternative. See COMP/38.784 - Telefónica, recitals 74 and 301-309.

48 C.f. COMP/38.784 - Telefónica, recitals 316-324 and 397-511 and case T-336/07 - Telefónica, SA and Telefónica de España, SA v European Commission, recitals 187-194 and 252-264.
} 
portion of joint and common costs and a margin upstream with initial one-time costs allotted over 3 years. ${ }^{49}$ For the retail price, an average had to be calculated, as broadband products were available in different versions, while two different models found use for the purpose of estimating the profits generated on a customer relationship. A traditional calculation of revenue and costs was performed for different periods, referred to as period by period methods and, as an alternative discounted cash flow, ${ }^{50}$ referred to as net present value methods or DCF. Under DCF, the profitability of a business over a reasonably long period must be assessed for the purpose of evaluating whether initial (startup) losses could be offset against later gains making these commercially justifiable. ${ }^{51}$ By using the as-efficient competitor test the Commission had, according to itself, allowed the dominant firm to benefit from its economics of scale and scope, ${ }^{52}$ and accept (minor) initial losses likely to be recouped later. On the other hand, testing was done for each of the separate wholesale products for the purpose of securing a reasonable margin, regardless of the requested access level. ${ }^{53}$ This in our view was also a decision clearly made to support the competitor's ability to climb the ladder of investment, i.e. a clear regulatory objective, not one governed by consumer welfare or competition law. ${ }^{54}$ While claiming to be using an as-efficient competitor standard, the substantial considerations offered to the competitors' business strategy and ability to climb the investment ladder does not in truth support this. The Commission even explicitly reserved the right to use a reasonably efficient competitor standard. ${ }^{55}$

Neither the General Court nor the European Court of Justice had any objections against the Commission's approach, and the former added two notable observations. Firstly, when offering an explanation for the anti-competitive effect of a margin squeeze, the General Court took the view that a margin squeeze raises the competitor's costs by market entry and delays their prospects of becoming profitable, by making it more difficult to establish a

\footnotetext{
49 The Commission declined to use the average lifetime of a customer relationship as done in previous cases in favour of a three year period c.f. recitals 477-489. This decision was motivated by the principles applied by NRAs and the tendency for customers to remain artificially long with the dominant undertaking due to a lack of competition. In case AT.39678/AT.39.731 - Deutsche Bahn I/II, recital 51, note 51 the Commission does, however, accept this as a novelty not compatible with the normal approach.

50 COMP/38.784 - Telefónica, recitals 325-349. In Wanadoo, at recitals 90-96, the Commission rebutted the applicability of the DCF model due to practical problems and a risk of over-optimistic analysis. The same reservations can be traced in Telefónica and c.f. Liyang Hou, Competition Law and Regulation of the EU Electronic Communications Sector, Wolters Kluwer 2012, p. 227 on sector regulation.

${ }^{51}$ C.f. COMP/38.784 - Telefónica, recitals 350-385: substantial intellectual efforts had to be invested into making the DCF analysis workable, including estimating the terminal value of assets and their average lifespan.

$52 \quad$ C.f. COMP/38.784 - Telefónica, recital 314.

53 C.f. COMP/38.784 - Telefónica, recitals 389-396.

54 See Martin Cave, The Ladder of Investment in Europe, in retrospect and prospect, Telecommunications Policy, 2014 Vol. 38, 8-9, 674-683.

55 C.f. COMP/38.784 - Telefónica, recitals 311-312.
} 
customer base capable of justifying the roll-out of their own infrastructure. ${ }^{56}$ While neither a definition nor an applicable test, this explanation does in our view offer justification for viewing margin squeeze as a separate infringement of Article 102 TFEU, as it could discourage market entry at a newly liberalized market, impeding the long-term interest of the consumer. Secondly, competition law has the ability to act as a substitute for ineffective sector regulation. This is confirmed (directly) through the sentence, "Thus, the competition rules laid down in the EC Treaty supplement, by ex post review, the regulatory framework adopted by the EU legislature for ex ante regulation of the telecommunications markets. "57 This comment is a remarkable point of departure for competition law in this sector, and one that uniquely shapes market definition.

\section{(c) Other cases contributing to margin squeeze $e^{58}$}

Aside from the case law setting out the consensus position on margin squeeze, there is something of a "patchwork quilt" of various elements of decisional practice and soft law guidance which can provide direction across the EU as to the enforcement of margin squeeze. Elements of what not to consider a margin squeeze are available in the case of Wanadoo, ${ }^{59}$ from 2003 a case pursued as a predatory pricing case, most likely in our view motivated by the absence of a vertically integrated $100 \%$ owned subsidiary. The case is problematic in a number of ways, and employs an obviously inconsistent methodology to support a particular and different outcome. Further, while initially opened as an excessive pricing case, the Commission would later change $K P N^{60}$ into a margin squeeze case due to the vertical link to the parent company retaining full decision-making control over the business of the subsidiary. However, no abuse was found on the facts in KPN and the case was eventually closed. Both cases indicate vertical integration is a necessary precondition for a finding of a margin squeeze infringement.

\footnotetext{
56 C.f. Case T-336/07 - Telefónica, SA, recital 279.

57 Case T-336/07 - Telefónica, SA, recital 293.

58 A margin squeeze could also be identified in COMP/39.653 - Vivendi, Iliad / France Telecom, COMP/39.707 - Si.mobil/Mobitel and case COMP/71.480 - Telenor. The two first where closed by the Commission absent a clear infringement while the latter still are pending. Finally, a margin squeeze might also have been presence in COMP/38.436 - QSC AG/Deutsche Telekom AG, closed following adjustment of the applied tariffs.
59 Case COMP/38.233 - Wanadoo Interactive.
60 COMP/37.704 - MCI/Mobile Termination Rates \& IP/02/483 - Commission suspects KPN of abusing its dominant position for the termination of calls on its mobile network and XXXIV Report on Competition Policy (2004), recital 47. The case originated from Price surveys, XXVIII Report on Competition Policy (1998), recital 79 and is therefore originally an excessive pricing case.
} 
An element of margin squeeze was also present in Deutsche Bahn I/II ${ }^{61}$ from 2013, where tariffs and discounts for the delivery of traction current were fixed in a manner beneficial to Deutsche Bahn's own activities, potentially squeezing an as-efficient competitor. The case was eventually closed but an assessment was performed using the principles set out in TeliaSonera and Telefónica. ${ }^{62}$ These included testing against an asefficient competitor's and the dominant undertaking's own costs while reserving the right to use alternatives. Further, not used in support of any point of legal consequence, it was nevertheless noted that an overall leverage plan is identified in internal documents. ${ }^{63}$ Margin squeeze is also discussed in a number of notices from the Commission. In its Access Notice ${ }^{64}$ from 1998, dealing with the telecom sector, two standards are contemplated. The dominant undertakings ability to compete downstream, had it been charged its own wholesale price, i.e. an as-efficient competitor test, or as an alternative if the margin allows a normal profit for a hypothetical competitor i.e. a reasonably efficient competitor. Embedded in the later is the securing of a reasonable profit for the competitor and the elimination of advantages purely linked to economics of scale and scope. This consideration was accepted later in TeliaSonera, save from the ranking of the reasonably efficient competitor standard as a secondary test rather than a direct alternative to the as-efficient competitor standard. ${ }^{65}$

The Commission Enforcement Paper ${ }^{66}$ from 2009 is also notable for defining margin squeeze as a form of refusal to supply requiring that wholesale products could be labeled as essential for access to the retail market. ${ }^{67}$ This was a principle, regrettably in our view, not accepted in Telefónica. ${ }^{68}$ Further, the paper noted that the applicable cost standard should be

61 AT.39.678/AT.39.731 - Deutsche Bahn I/II, recital 42-66. See also case COMP/39.402 - RWE gas foreclosure, recitals 29-36.

62 Despite the discriminatory element the case are pursued as a margin squeeze case.

63 See AT.39678/AT.39.731 - Deutsche Bahn I/II, recital 48. See also Jean-Christian Le Meur, Iratxe Gurpegui \& Katja Viertiö Margin squeeze in the Spanish broadband market: a rational and profitable strategy, Competition Policy Newsletter 3 - 2007, 27 stating that the foreclosure risk could not have eluded the attention of Telefónica indicating a malicious intent in the case.

$64 \quad$ Notice on the application of the competition rules to access agreements in the telecommunications sector - framework, relevant markets and principles. O.J. 1998C 265, pp. 2-28, recitals 117-118.

$65 \quad$ C.f. TeliaSonera, recital 45.

66 Communication from the Commission - Guidance on the Commission's enforcement priorities in applying Article 82 of the EC Treaty to abusive exclusionary conduct by dominant undertaking, recital 75-90.

${ }^{67}$ See also General Opinion of Mr. Advocate General Mazák in case 52/09 - Konkurrensverket v TeliaSonera Sverige $A B$, ECR 2011 p. I-527, at recital 18 suggesting that the Court of Justice should accept the same principle.

68 In support of disregarding this the Commission does in COMP/38.784 - Telefónica, recitals 302-309 refer to the infrastructure as predating market opening and the fruits of special or exclusive rights and that relevant balancing of interest and incentives already has been made by the regulator compelling Telefónica to supply at regulated tariffs. 
LRAIC, potentially corrected for economics of scope, ${ }^{69}$ ensuring coverage by the retail prices. Thereby the papers settles on a specific cost standard rather than the average avoidable cost (AAC) principle generally favoured by the Enforcement Paper. Further developments are attempted with two papers from ERG. In the ERG Remedy Paper from $2006,{ }^{70}$ directed to NRAs, the applicable cost standard is argued to be the internal costs rather than factual charges, indicting the adoption of a non-discrimination obligation. Further, when calculating cost economic of scale and scope should be eliminated jointly with inefficiencies. The ERG margin squeeze paper, ${ }^{71}$ from 2009 adds additional considerations by finding that a margin squeeze, at least in theory, should require a substantial level of dominance at wholesale level and a product being indispensable for access to the retail margin. A margin squeeze could further be established by considering the dominant undertakings ability to be profitable at the retail level in light of the charged wholesale prices, i.e. an as-efficient competitor standard; or a margin to secure access plus a normal profit for a hypothetical competitor, i.e. a reasonably efficient competitor standard. Both papers have been developed for the purpose of contemplating sector regulation but the considerations have value for the understanding of margin squeeze under Article 102 TFEU.

\section{An emerging, but not necessarily prudent, enforcement consensus?}

We consider that the Deutsche Telekom case indicates that a consensus position has emerged for EU margin squeeze enforcement on fixed line markets. This is founded upon the identification of the infringement as a separate category of abuse under Article 102 TFEU, ${ }^{72}$ regardless of regulatory overview by NRAs for telecoms markets. From an enforcement perspective, it is difficult not to conclude that what constitutes a "sufficient" margin remains a complex issue, driven by national market features, the product choices and conduct of the dominant firm, available data for the evaluation of competitive dynamics by an NRA, and the policy priorities of various institutions, not least the Commission and the NRAs. This is so even when the NRA had failed in their obligation ex post to restrain the risk, making higher retail prices the sole available remedy for the dominant undertaking for stopping the abuse. However, we consider that recognizing this consensus is not the same as taking a favorable

\footnotetext{
$69 \quad$ See recital 26 , note 18.

70 Revised ERG Common Position on the approach to appropriate remedies in the ECNS regulatory framework (ERG (06)33), 2006, see in particular pp. 121-122.

71 ERG report in the discussion on the application of margin squeeze tests to bundles (ERG (09) 07).

72 A degree of uncertainty can be detected in the Commission decision. C.f. case COMP/37.451 Deutsche Telekom AG, O.J. 2003L 263/9, recital 199 where the abuse is defined as consisting of “...charging unfair prices...caught by Article 82(a) of the EC Treaty", labelling margin squeeze as a form of excessive pricing.
} 
view on the issue, in particular when sector-specific regulation is engaged. We therefore make a number of critical points about the difficulties associated with the consensus position.

Firstly, we would like to point out that a common feature of the Deutsche Telekom and Telefónica cases was a failure by the NRA to remedy adequately the margin squeeze risk ex post, despite the clear EU treaty obligation for this. ${ }^{73}$ This is a classic "Type II" failure of enforcement. In both cases the NRA had either positively viewed the available margin as sufficient for newcomers or failed to take the margin into consideration properly for enforcement purposes. The guilty were not convicted. We consider that the Commission could, perhaps, have pursued the cases under Article 258 TFEU (failure to implement EU laws) rather than Article 102 TFEU, and in fact it appears that the Deutsche Telekom case originally started out in this manner. ${ }^{74}$ Ultimately, it was either considered more correct, or perhaps more beneficial, to pursue the case against the dominant undertaking, rather than the Member State concerned. The ability to use competition law where sector regulation is ineffective (or vice versa) seems to have been confirmed by the General Court in Telefónica. ${ }^{75}$ We consider that this is a troubling development and opened up a somewhat dubious role for the margin squeeze infringement in the long run, given our later thoughts on technological convergence.

Secondly, the case law demonstrates how the actual applied legal standards in both Deutsche Telekom and Telefónica were heavily influenced by regulatory considerations. ${ }^{76}$ Both cases introduced significant novelties in respect of the methodologies for calculating costs and revenue. In Deutsche Telekom, ${ }^{77}$ the wholesale price, levied for the competitor, was calculated using the regulated wholesale price, including a surplus for opening or taking over a connection stipulated by sector regulation, while the revenues did not include dial-up charges regardless of the generated cash flow. The case therefore seems to us to be a decision primarily motivated by sector regulation making a distinction between charges for subscription and the actual use. Further, the Commission justified its decisions on methodology by referring to the need to secure competitors access for competing with that

\footnotetext{
73 See e.g. Council Regulation 2887/2000 (LLU Regulation) recital 10.

74 Case COMP/37.451 - Price squeeze local loop Germany, recital 4. For further, see Robert O’Donoghue \& Jorge Padilla, The Law and Economics of Article 102, $2^{\text {nd }}$ Edition Hart Publishing 2013, pp. 418, note 210.

$75 \quad$ Case T-336/07 - Telefónica, SA, recital 293.

76 In principle could be tabled that the mere pursuing of cases in a regulatory environment would reduce competition law to an instrument of securing correct and full implementation of sector regulation rather than a stand-alone form of regulation.

77 Case COMP/37.451 - Deutsche Telekom AG, O.J. 2003L 263/9, recital 111 (weighted average), recitals 112-137 (retail revenue), 138-141, 155-159 (product cost) and 149-151 (wholesale price).
} 
dominant undertaking and to replicate its customer pattern. ${ }^{78}$ Regardless of any sympathies' for the expressed consideration, it should not be ignored that competition law in this case inescapably acquired the flavour of sector-specific regulation. This position was taken even further with Telefónica where the costs, calculated as LRAIC, ${ }^{79}$ based on variable and fixed costs, also included a portion of joint and common costs in addition to a margin upstream, with initial one-time costs allotted over 3 years. ${ }^{80}$ Traditionally "average lifetime" has been applied to the latter, and while the adjustment might be justifiable, the choice is not fully explained in our view beyond reference to principles developed and applied by sector regulators and the risk of producing overoptimistic estimation unless corrected. ${ }^{81}$ With respect to the retail price, the Commission had, as an alternative method, $\mathrm{DCF}^{82}$, for the purpose of calculating a net present value, despite rebutting this approach in other cases. ${ }^{83}$ While claiming to apply the most favorable test for the dominant undertaking, when testing the margin, this was done for each separate wholesale product for the purpose of securing a reasonable margin, regardless of the requested access level. ${ }^{84}$ This decision was arguably made to support the competitor's ability to climb "the ladder of investment" (i.e. a consensus regulatory objective ${ }^{85}$ ) and to allow the Commission to reserve the right to secure market entry for less effective competitors. ${ }^{86}$ This is in our view an objective difficult to align with the notion of competition law grounded in a short run consumer welfare standard.

Thirdly, what can be demonstrated by the TeliaSonera ${ }^{87}$ case is that it is not unproblematic to accept margin squeeze as a separate standard of abuse, subject to a potentially less rigid standards than sector-specific regulation. In TeliaSonera, wholesale access had been granted without legal obligation and in a situation where the conditions for a

78 Case COMP/37.451 - Deutsche Telekom AG, O.J. 2003L 263/9, recital 127.

79 C.f. COMP/38.784 - Telefónica, recital 316-324 and 397-511 and case T-336/07 - Telefónica, SA and Telefónica de España, SA v European Commission, recitals 187-194 and 252-264.

80 The Commission declined to use the average lifetime of a customer relationship as done in previous cases in favour of a 3 year period c.f. recital 489. In case AT.39678/AT.39.731 - Deutsche Bahn I/II, recital 51, note 51 the Commission does, however, accept this as a novelty not compatible with the normal approach.

81 COMP/38.784 - Telefónica, recital 477-488. In recital 478, it is noted how "Telefónica's subscribers' average lifetime is likely to be higher than it would be in a competitive market, as a consequence of the market power of the dominant undertaking." A consideration meriting correction followed by labelling the phenomenon as a form of cellophane fallacy-problem c.f. note 493.

82 COMP/38.784 - Telefónica, recitals 325-349.

83 See COMP/38.233 - Wanadoo Interactive, recitals 90-96 for example of the Commission rebutting the applicability of the DCF model due to practical problems and a risk of over-optimistic analysis.

C.f. COMP/38.784 - Telefónica, recitals 389-396.

85 See Martin Cave, The Ladder of Investment in Europe, in retrospect and prospect, Telecommunications Policy, 2014 Vol. 38, 8-9, 674-683.

86 C.f. COMP/38.784 - Telefónica, recitals 311-312.

87 Case C-52/09 - Konkurrensverket mod TeliaSonera Sverige AB, ECR 2011, p. I-527, recitals 6 (voluntarily opening) 34, 55-58 (separate infringement), 31-33, 45 (legal standard), 72 (indispensability) 89 (dominance at one or two markets) and 96-103 (recoupment). 
refusal to supply case under Article 102 TFEU most likely was not meet. This risked rendering a situation where the dominant undertaking could improve its legal position, and ultimately its commercial position, by creating burdens for competitors as seen in Deutsche Telekom and Telefónica. Further, against Telefónica and TeliaSonera, the Commission would later table the argument that constructive refusals to supply should be reviewed subject to less rigid doctrine compared to traditional refusals. ${ }^{88}$ With TeliaSonera the requirement of longterm recoupment, factual exclusion or dominate position at both wholesale and retail level where also rebutted. What potentially makes this troublesome in our view can be seen by revisiting $K P N{ }^{89}$ In the course of this case, it appears that the Commission shifted between viewing the case as an expression of (a) discrimination, (b) constructive refusals to supply, (c) excessive (buying) price before finally settling on the margin squeeze approach, ${ }^{90}$ and, on a side note, ultimately dropping the case partly following intervention by the NRA under sector regulation. ${ }^{91}$ Under a doctrine void of a requirement of dominant position at both wholesale and retail level, the line between margin squeeze and other forms of abusive conduct becomes in our view somewhat blurred, providing for opportunistic behavior from accusers (and in principle also defenders) when making allegations of margin squeeze for strategic reasons before competition authorities or NRAs.

Fourthly, it is possible to read TeliaSonera ${ }^{92}$ in a manner where the margin need not even be negative for an abuse to be identified. This follows explicitly from the offered considerations where the Court notes that, "If, [the] margin remains positive, it must then be demonstrated that the application of that pricing practice was, by reason, for example, of reduced profitability, likely to have the consequence that it would be at least more difficult for the operators concerned to trade on the market concerned." While from a regulatory perspective it might be reasonable to consider it problematic in the long run when profitability is reduced, we fail to see the relevance of this consideration under competition law. In particular, this consideration might inescapably open a floodgate of discussion on what to may be considered to be a "normal profit". We therefore consider (as with Petit) that the argument that there should be a profit most likely has been made redundant by Post

\footnotetext{
88 See COMP/39.525 - Telekomunikacja Polska, recitals 704 and 803-807.

89 COMP/37.704 - MCI/Mobile Termination Rates.

90 See IP/02/483 - Commission suspects KPN of abusing its dominant position for the termination of calls on its mobile network. Press release from the Commission 27 March 2002.

91 C.f. XXXIV Report on Competition (2004), recital 47.

92 Case C-52/09 - Konkurrensverket mod TeliaSonera Sverige AB, ECR 2011, p. I-527, recitals 73-74. For further on this reading see Nicolas Petit Price Squeezes with positive margins in EU competition law: Economic and legal anatomy of a zombie, SSRN, (2014).
} 
Danmark $I^{93}$ from 2012, where the Court of Justice refused to consider a pricing practice abusive when coverage of incremental costs was secured. In our view, TeliaSonera has been overruled by Post Danmark I on this point.

Fifthly, embedded within cases as Deutsche Telekom and Telefónica are a large number of decisions normally taken beforehand by the Commission within a competition investigation on cost and revenue methodology. These include choice of the average lifetime of a customer relationship and telecoms equipment; measures of capital expenditure and cost; the terminal value of assets; and which products and services to include and which not to include. As detailed above, the Commission has often resorted to potentially idiosyncratic principles developed and applied under sector regulation rather than what might be thought of as "general accepted business principles". ${ }^{94}$ Whilst any regulatory exercise is to some extent necessarily artificial, such a process should in our view be supported by evidence to evaluate the actual experience of market conduct as possible. It should be obvious for any biases to be corrected self-consciously, but each time an enforcer is confronted with more than one option, a choice must be made either to use a standard of evaluation beneficial to a complainant or run the risk of wrongly identifying behavior as an abuse, a Type I-error.

Hence, it could be argued that, rather than condemning margin squeeze as per se anticompetitive and a self-standing infringement of Article 102 TFEU, it should be viewed as a variation of other forms of infringement, and only be condemned under these abuse of dominance standards. Alternatively, margin squeeze should as a minimum not be appraised entirely void of principles and considerations advanced under these standards. Our argument is in line with our initial opening remarks in this paper on how margin squeeze could be seen as variation of excessive and predatory pricing or discrimination, and should be rendered subject to the same principles as a refusal to supply. This is a consideration linked to the initial presentation of two types of enforcement mistakes. A Type I-error occurs where intervention, under competition law, is made against actions failing to meet the developed standards, and principles, for competition on the merits; and Type II-errors where anticompetitive abuse eludes intervention. In light of the (initially) under-developed standards in the early practice for appraising margin squeeze the prospect of both errors remains real in our view. However, lately it appears that the risk of Type I-errors and over-enforcement, have become more prominent, and the actual standards under influence by sector considerations,

93 Case C-209/10 - Post Danmark v. Konkurrencerådet ECR 2012 I-0000.

$94 \quad$ Presuming sector regulation largely uses such general accepted principles, the choice might be less controversial. However, no guarantee of this can be made. 
dilutes the purpose of competition law to a level where the influence takes the form of pollution.

\section{Technological convergence and market definition: muddled margins or muddled methodologies?}

Having considered the EU competition law enforcement consensus critically, in this section we propose a hypothetical example to illustrate how technological convergence poses peculiar challenges for margin squeeze enforcement across converging markets. Our example considers the pricing behavior of a vertically-integrated undertaking dominant in one or more telecoms markets, making a bundled offering to consumers with the intention of excluding competitors by pricing below cost. This evaluates competition at the retail level for bundled products, in distinction to prior cases before the European Courts.

\section{(a) A renewed focus on consumers}

In this hypothetical we place a renewed focus on the benefit of competition for consumers. This consumer focus is the rationale for competition law enforcement, and we feel that it has got lost in the consensus position on margin squeeze. The difficulty for enforcement purposes is the ability of the dominant firm to price across markets as traditionally defined. Our hypothetical example is of a bundled offering to consumers by a multi-product firm dominant in one or more upstream or downstream telecoms markets. The bundle is priced with the intention of squeezing margins for access competitors. Our argument is that, through innovative pricing, the dominant firm can lawfully squeeze intermediate margins without infringing Article 102 TFEU under the consensus position. ${ }^{95}$ Barring "smoking gun" email evidence of exclusionary intent discovered (for example) during a competition investigation, in our hypothetical, the dominant firm can lawfully price its services "on the merits" and leave an inadequate margin for competitors that will not cover costs. This example indicates to us that there are a series of gaps in the law which can only at present be dealt with through prospective regulation, and that the use of ex ante regulation in the form of competition law is in our view questionable. Market structure, and in particular whether the fact of vertical integration is beneficial to consumers, is also a relevant consideration for prospective regulation. Our example calls into question whether

95 C.f. COMP/38.784 - Telefónica, recitals 386-388 the Commission consider which retail level to undertake the testing settling on an aggregated level rather than testing each separate offer. Hence, the Commission appears to be aware of the risk of what we later refer to as a muddled margins squeeze. 
vertical integration is a beneficial phenomenon for consumers, as it allows dominant firms to hide costs or redistribute them in ways not easily assessed ex post by competition authorities. This is a problem recognized in other industries, in the presence of collusion or not. ${ }^{96}$ However, the structure of the telecoms sector (dependent on infrastructure access usually owned by the fixed line incumbent) makes this problem particularly acute.

The chart below illustrates our hypothetical by setting out in simple fashion the costs of individual products within an offering. The dominant firm has two potential offerings (A and B) of four bundled retail products (1-4) at the same overall retail price, which are also sold wholesale at a mandated access price. Consumer demand will be met: it is technologically feasible and attractive to consumers to offer this bundle. Each of the four products is potentially a separate retail market, if a competition authority chose to define and evaluate margins across that market for margin squeeze purposes. There is a mandatory, prospectively provided access margin between products 2 and 4, set ahead of time by the NRA, under sector regulation, so competitors can purchase these products wholesale to resell to consumers profitably. By giving away product 4 free of charge at retail as part of offering B, the dominant firm has successfully "muddled" the margins between the prices in different

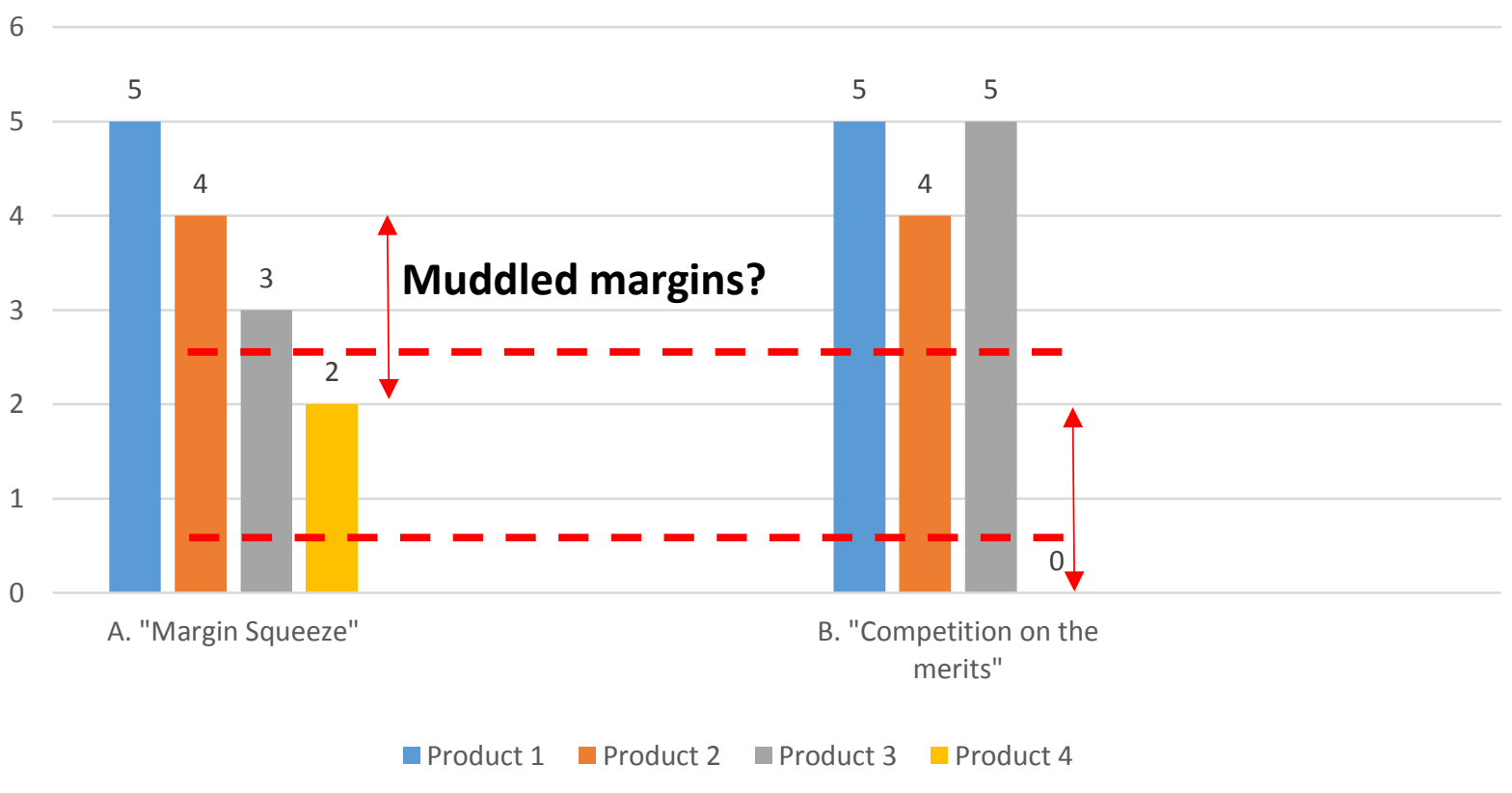

markets, whilst preserving the regulated access margin, and has done so at a price which no access competitor can compete profitably at. The margin for profit simply is not there. The

96 See Section 10 in the UK Competition Commission Phase 2 investigation of the UK market for aggregates, cement and ready-mix concrete (14 January 2014) as to vertical integration in the cement industry, which was subject to a concurrent cartel investigation under Article 101 TFEU across the EU by the Commission. See also Nocke V., and White L., Do vertical mergers facilitate upstream collusion? (2007) American Economic Review 96: 1321-1339. 
dominant firm can make this offering particularly attractive given the nature of the notionally "free" product, such as certain aspects of desirable broadband connectivity or premium broadcast content.

What is the incentive for the dominant firm to engage in this bundling? In a single word, exclusion. The advantage of this conduct is a quiet life. Competitors are not able to enter effectively, gain a market reputation amongst consumers, nor match with competitive pricing the range of the product offerings in Bundle $\mathrm{B}$. What are the implications of this hypothetical conduct for ex post competition law enforcement? Firstly, the level of aggregation chosen in evaluating the offering is relevant: is the margin to be measured across an individual product or a whole portfolio? Our hypothetical indicates that, the higher the level of aggregation chosen by an enforcer, the greater the flexibility for dominant firm to allocate common costs across services and customers. The problem for any competition authority in evaluating whether this conduct is lawful ex post is complexity and innovation on the part of the dominant company. What are the appropriate choices for a competition authority as to methodologies for evaluating costs? A decision to evaluate costs at a particular level can always be taken at a more granular level, and capture elements of costs which are used to support notionally 'free' services 'given away' to consumers below cost, and which in our view has the effect of muddling margins on the overall bundle. It is important to note that in our example all of these four products are retail products, which sits in distinction to the Telefónica case, where the Commission performed a margin squeeze assessment for solely wholesale products.

Recently, these enforcement choices faced Ofcom, the UK's dual NRA and competition authority for telecoms, in the TalkTalk non-infringement Competition Act enforcement decision of 2014, where the allegation of margin squeeze was made by an access competitor against the fixed line incumbent's behavior in making a bundled offering across converging markets. ${ }^{97}$ The bundled offering in question of the dominant undertaking concerned premium sports content offered with superfast broadband. In its treatment of the methodology for assessing margin squeeze, Ofcom emphasized that whether to include the costs of one or more products in the margin evaluation was fundamental:

"For the purpose of this no grounds for action decision, we include Pay TV in our analysis on the basis that BT TV is retailed as an add-on that can only be purchased by BT broadband subscribers and so

97 See also the European Commission's treatment of this in Case COMP/38.784 Telefónica, recitals 386388: "This approach (referred as to the "aggregated approach") is based on the principle that competitors must at least be able to profitably replicate Telefónica's product pattern." (388). 
we consider that it constitutes part of BT's offering to broadband subscribers. If triple-play packages were not taken into account BT would then appear to be setting an adequate margin, based solely on its dual-play packages. However, assessed on an aggregate basis (i.e. looking across both dual play and triple play in aggregate) the margin could be negative." 98

Accordingly, the margin was assessed by Ofcom across the bundle of products, and was found to be sufficient to cover downstream costs, implying that an equally efficient competitor should have been able to compete with the fixed line incumbent across the portfolio of products. ${ }^{99}$ Yet the margin could not definitively be said to be sufficient, and effects were unclear in this dynamic market. This gap therefore required prospective regulation by Ofcom as NRA to monitor and enforce a sufficient access margin, rather than ex post competition law enforcement. ${ }^{100}$ We find such a conclusion as a matter of ex post margin squeeze consensus position problematic, along the argument expressed in this Working Paper, in that it does not allow for regulatory certainty when assessing margins across dynamic and technologically converging telecoms markets. The incumbent has both the incentive and ability to "muddle" margins through the bundle of products which the access competitor simply cannot do. This problem calls into question whether the consensus position on margin squeeze can ex post adequately assesses competition on these markets.

\section{(b) Risks of methodological errors}

We therefore suggest that the innovation of products caused by technological convergence creates a series of gaps for enforcing margin squeeze across converging markets. These gaps can be either "Type I" or "Type II" errors, which are reflected in the case law above. We are agnostic as to which kind of error (Type I or Type II) these gaps risk creating. The gaps can be expressed typologically, as they arise from particular vertical aspects of the unilateral conduct under assessment:

\begin{tabular}{|c|c|}
\hline Economic Phenomenon & Regulatory Gap \\
\hline \multirow{3}{*}{ Vertical Integration } & - Permits pricing conduct to intentionally muddle \\
& margins between different products: bundling and \\
& opaque cost evaluation across markets. \\
\hline & \\
\hline
\end{tabular}

$98 \quad$ Ofcom TalkTalk (CW/01103/03/13) (20 June 2013) at para. 5.74.

99 Ofcom TalkTalk (CW/01103/03/13) (20 June 2013) at paras. 7.49 and 7.54

100 Ofcom, Fixed Access Market Reviews: Approach to the VULA Margin, (19 March 2015) 


\begin{tabular}{|l|ll|}
\hline $\begin{array}{l}\text { Indispensable or } \\
\text { Necessary input? }\end{array}$ & $\begin{array}{l}\text { Technological innovation might render input } \\
\text { irrelevant or substitutable on one or more markets. }\end{array}$ \\
\hline - Dominant upstream & $\begin{array}{l}\text { Technological innovation might undermine } \\
\text { dominance even if this continues to be required by } \\
\text { cosition }\end{array}$ & $\begin{array}{l}\text { Technological innovation might make the purposes } \\
\text { of downstream activity different to those set out in } \\
\text { the consensus margin squeeze position. }\end{array}$ \\
\hline Active downstream? &
\end{tabular}

\section{(c) Final conclusions}

As a consequence of accelerating technological convergence which impacts the way telecommunications services are consumed, we believe that a series of regulatory gaps identified in the typology above have appeared in the past years in the ex post enforcement of margin squeeze. This paper has attempted to identify these gaps from the case law and argue for the need for them to be addressed by EU competition authorities in enforcing competition law. The margin squeeze decisional practice of various enforcers reflected in the case law has so far shown sensitivity to dynamic competition and product innovation. We make a number of critical comments on the consensus position. Yet there may be some clear regulatory gaps emerging from the mature decisional practice as this is applied across converging telecoms markets. We are agnostic as to what type of enforcement "error" these gaps risk creating. On the one hand, we can see some potential Type I-errors in the current development of the margin squeeze concept to abuse, while on the other hand we can also identify Type II-errors. If we assume there was in fact a margin squeeze infringement in the Telefónica, TeliaSonera and Deutsche Telekom cases, and an enforcer used competition law to correct this, potentially such considerations could be said to have "polluted" the objectives of competition law. The decisional practice is a long way from consumer welfare. Equally, if an attempt is made to remedy Type-II errors in prospective regulation by more vigorously applying competition law, this is also surely problematic.

We consider that the decisional practice and guidance on margin squeeze from the centre is flexible enough to allow discretion for NRAs and EU competition authorities to innovate and respond to market developments, either by consciously evaluating margins 
across formerly separate markets or by adjusting costs forming part of the revenue and costs of the dominant firm. A prudent balance must, however, be secured which in light of the described errors could involve accepting that competition law might be less suited for this than ex ante prospective sector regulation. For this reason, we welcome further EU-wide regulatory co-operation to supervise the enforcement of margin squeeze against a backdrop of dynamic technological convergence within the EU. In this paper, we have discussed what we see are some of the flaws involved in the consensus position as to ex post margin squeeze competition enforcement in telecoms. Our view is that the abuse as it has reached a present consensus, whilst coherent, is poorly suited to future technological development in the telecoms sector, where margins between different offerings can be 'muddled' through bundling a variety of different services in a single price for consumers. Under conditions of accelerating convergence, we see a risk of Type-I errors as to ex post competition law enforcement and Type-II errors under ex ante sector regulation. However, the risk of the latter Type II error should not in our view be mitigated by increased use of competition law due to the risk of pollution of the objectives of competition law with sector regulation. Our view is that the decisional practice of the Commission, competition authorities and NRAs and will have to evolve in line with developing technological innovation. Further, this development might even call for a higher degree of resorting to sector regulation applied $e x$ ante, which perhaps even ultimately precludes any subsequent ex post review under competition law. 


\section{References}

\section{a. Theory}

Martin Cave, 'The Ladder of Investment in Europe, in retrospect and prospect', Telecommunications Policy, Vol. 38, 8-9, (2014) 674-683

Tobias Caspary and Lars Görlitz, "EU Merger Control and Mobile Telecoms - consolidation at the cost of competition or regulation hampering the creation of European champions?", (2015) 36 ECLR, Issue 5, 211-299

Niamh Dunne, "Margin Squeeze: Theory, Policy, Practice", 33 European Competition Law Review 29 \& 61 (2012)

Geoff Edwards, Margin squeezes and the inefficient "equally efficient" operator, ECLR 2011, 32(8)

Damien Geradin and J. Gregory Sidak, "European and American Approaches to Antitrust Remedies and the Institutional Design of Regulation in Telecommunications", American Enterprise Institute (2005)

Liyang Hou, Competition Law and Regulation of the EU Electronic Communications Sector, Wolters Kluwer 2012

Jullien, Rey and Saavadra, “The Economics of Margin Squeeze,” October 2013

John Kallaugher, "The "Margin Squeeze" under Article 82: Searching for Limiting Principles,” paper from Global Competition Law Centre (GCLC) (10 December 2004)

Jean-Christian Le Meur, Iratxe Gurpegui \& Katja Viertiö Margin squeeze in the Spanish broadband market: a rational and profitable strategy, Competition Policy Newsletter 3 2007

Maria Maher, "Competition policy trends in telecommunications", (MLEX magazine, October-December 2012, pp. 46-49)

Massimo Motta, Competition Policy, Theory and Practice, (Cambridge, 2004)

Nocke V., and White L., Do vertical mergers facilitate upstream collusion? (2007) American Economic Review 96: 1321-1339 
Robert O'Donoghue \& Jorge Padilla, The Law and Economics of Article 102, $2^{\text {nd }}$ edition, Hart Publishing, 2013

Nicolas Petit Price Squeezes with positive margins in EU competition law: Economic and legal anatomy of a zombie, SSRN, (2014)

\section{b. Case Law}

Amicus Curiae brief, Robert Bork and Gregory Sidak in Pacific Bell v. LinkLine 555 U.S. 438 (2009)

76/185/ECSC: Commission Decision of 29 October 1975 adopting interim measures concerning the National Coal Board, National Smokeless Fuels Limited and the National Carbonizing Company Limited O.J. 1976L 35/6.

Case C-209/10 - Post Danmark v. Konkurrencerådet ECR 2012 I-0000

Case T-5/97 - Industrie des poudres sphériques SA, ECR. 2000, p. II-3755

Case C-52/09 - Konkurrensverket mod TeliaSonera Sverige AB, [2011] ECR I-527

Case COMP/38.784 - Telefónica

Case T-336/07 - Telefónica, SA and Telefónica de España, SA

Case C-295/12P - Telefónica SA and Telefónica Espana

COMP AT.39.678/AT.39.731 - Deutsche Bahn I/II

COMP/39.402 - RWE gas foreclosure

COMP/39.653 - Vivendi, Iliad / France Telecom

COMP/39.707 - Si.mobil/Mobitel

COMP/71.480 - Telenor

COMP/38.436 - QSC AG/Deutsche Telekom AG

COMP/38.233 - Wanadoo Interactive

COMP/37.704 - MCI/Mobile Termination Rates \& IP/02/483 - Commission suspects KPN of abusing its dominant position for the termination of calls on its mobile network

Case IV/30.178 - Napier Brown - British Sugar, O.J. 1988L 284/41

Case T-271/03 - Deutsche Telekom, ECR 2008, p. II-447

Case C-280/08P - Deutsche Telekom, [2010] ECR I-9555

Case COMP/37.451 - Deutsche Telekom AG, O.J. 2003L 263/9

AT\&T v. Iowa Utilities Board, 525 U.S. 366 (1999) 
Final, 25 June 2015

Cavad Communications v. Bell Atlantic Corp., 398 F.3d 666 (D.C. Cir 2005)

M.7419, TeliaSonera / Telenor JV

Ofcom, Competition Act Final Decision, Thus / Gamma (CW/00988/06/08) (20 June 2013)

Ofcom, Competition Act Final Decision, TalkTalk, (CW/01103/03/13) (21 October 2014)

\section{c. Regulatory Statements etc}

XXXIV Report on Competition Policy (2004)

XXVIII Report on Competition Policy (1998)

Revised ERG Common Position on the approach to Appropriate remedies in the ECNS regulatory framework, (ERG (06)33), 2006

ERG (09) 07, Report on the Discussion on the application of margin squeeze tests to bundles (March 2009)

ITU, Competition and regulation in a converged broadband world, (February 2013)

OECD Policy Roundtables, (DAF/COMP (2009) 36) Margin Squeeze (9 September 2010) OECD Reports, Restructuring Public Utilities for Competition (August 2001)

Ofcom, Fixed Access Market Reviews: Approach to the VULA Margin, (19 March 2015) 